\title{
Evaluation of cytotoxic, apoptotic, mutagenic, and chemopreventive activities of semi-synthetic esters of gallic acid
}

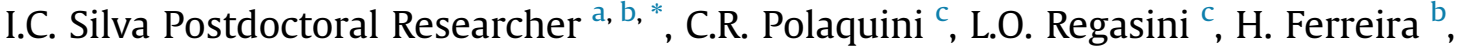 \\ F.R. Pavan, PhD Assistant Professor of Microbiology, Tuberculosis Research Laboratory a, ** \\ ${ }^{a}$ Faculdade de Ciências Farmacêuticas, UNESP - Universidade Estadual Paulista, Araraquara, São Paulo 14800-903, Brazil \\ b Departamento de Bioquímica e Microbiologia, Instituto de Biociências, Universidade Estadual Paulista, Rio Claro, Brazil \\ ${ }^{\mathrm{c}}$ Departamento de Química e Ciências Ambientais, Instituto de Biociências, Letras e Ciências Exatas, Universidade Estadual Paulista, São José do Rio Preto, \\ Brazil
}

\section{A R T I C L E I N F O}

\section{Article history:}

Received 16 January 2017

Received in revised form

3 April 2017

Accepted 24 April 2017

Available online 25 April 2017

\section{Keywords:}

Alkyl gallates

Toxicity

Micronucleus

DNA damage

Cell death

Chemoprotective

\begin{abstract}
A B S T R A C T
Gallic acid and its derivatives are phenolic compounds widely used as food supplements in the form of capsules, liquid extracts, and ointments owing to their good antioxidant properties. Besides, these compounds are potent inhibitors of fungi, bacteria, and some viruses and possess strong antiproliferative and chemopreventive activities. However, gallic acid derivatives are also known to exert harmful effects like mutagenicity and cytotoxicity. The present study aimed to understand and explore the toxicological risks of these compounds. For this, a series of alkyl gallates with side chains varying from five to eight carbons (pentyl, hexyl, heptyl, and octyl gallates) were evaluated for their cytotoxic and pro-apoptotic potential. In addition, the genotoxic effects of alkyl gallates were measured in HepG2 cells using the single cell gel electrophoresis (SCGE)/comet assay and the cytokinesis-blocked micronucleus (CBMN) test. In both the tests, the substances did not induce any significant differences when compared to the control group. In addition, alkyl gallates exhibited a chemopreventive effect, thereby considerably reducing the mutagenicity caused by $\mathrm{H} 2 \mathrm{O} 2$. In conclusion, our results suggest that alkyl gallates are nongenotoxic, non-mutagenic, and pro-apoptotic agents, which may serve as suitable and promising candidates for preventing chemically-induced chromosomal damage.
\end{abstract}

(๔) 2017 Elsevier Ltd. All rights reserved.

\section{Introduction}

Cancer is considered as one of the leading causes of morbidity and mortality, thereby posing a major challenge to the health professionals worldwide (Stewart and Wild, 2014). Oxidative stress, a term used to describe the imbalance between the generation of harmful free radicals and their elimination by the protective machinery of the body is an aspect common to all types of cancers (Noda and Wakasugi, 2001). A significant number of new drugs and pharmaceuticals have been developed displaying protection against the deleterious effects of oxidative stress; however, most of these drugs are also associated with adverse side effects, such as

\footnotetext{
* Corresponding author. Faculdade de Ciências Farmacêuticas, UNESP - Universidade Estadual Paulista, Araraquara, São Paulo 14800-903, Brazil.

** Corresponding author.

E-mail addresses: isabelcrs10@gmail.com (I.C. Silva), fernandopavan@fcfar. unesp.br (F.R. Pavan).
}

cytotoxicity, mutagenicity, and carcinogenicity (Garattini and Bertele, 2002; Bagchi et al., 2014).

In an attempt to develop a safe and non-toxic treatment for cancer with lower side effects, a special attention has been diverted to antioxidants extracted from plants and their semi-synthetic derivatives. Among them, gallic acid (GA), a natural plant triphenol and its derivatives have been demonstrated by several investigators to possess strong antioxidant activity (Aruoma et al., 1993; Morley et al., 2005; Savi et al., 2005; Locatelli et al., 2009; Merkl et al., 2010; Morais et al., 2010).

The gallic acid (3,4,5-trihydroxybenzoic acid) is a naturally occurring phenol present in plants and obtained by the hydrolysis of tannins (Inoue et al., 1995). Its alkyl esters, especially propyl gallate, octyl gallate, and lauryl gallate, are currently utilized as antioxidant additives to prevent changes in food flavor and nutritional values and increase the shelf-life of lipid-based foods by serving as chain-breaking inhibitors of oxygen-induced lipid peroxidation. The same property is exploited by the cosmetic and 
pharmaceutical industries (Aruoma et al., 1993; Fujita and Kubo, 2002; Kubo et al., 2002), where these compounds are employed as natural coloring agents and for drug formulations. The diverse range of properties of gallic acid and its derivatives has been associated with a wide variety of biological activities, including antifungal (Fujita and Kubo, 2002; Hsu et al., 2009), antibacterial (Kubo et al., 2002; Kubo et al., 2004; Silva et al., 2013), antiviral (Kratz et al., 2008), antiherpetic (Savi et al., 2005), antiproliferative (Dodo et al., 2008; Locatelli et al., 2008; Locatelli et al., 2009), and chemopreventive (Morley et al., 2005; Pandır, 2015).

Contrary to their versatile and beneficial properties, alkyl gallates have also exhibited controversial results. Some studies have demonstrated that gallates could induce DNA damage and mutagenicity (Tayama and Nakagawa, 2001; Furukawa et al., 2003; Savi et al., 2005), and their antioxidant potential can under certain conditions turn prooxidant (Strlic et al., 2002; Furukawa et al., 2003). For these reasons, the safety and biological effects of alkyl gallates would benefit of further toxicological investigations.

Toxicological risk assessment is considered as an essential part of a drug design initiative to identify compounds that are most likely to be detrimental to the human health. The evaluation of toxicological risk involves hazard identification, dose-response assessment, exposure assessment, and risk characterization. Both in vivo and in vitro toxicity methods are employed for a comprehensive and valid analysis of the risks associated with the exposure to potentially harmful substances. In vitro assay systems provide an important contribution in elucidating the mechanisms of toxicity, carcinogenicity, and metabolism of drugs and chemicals. Thus, they serve as an indispensable tool for identifying potentially hazardous compounds at early stages of drug design (Davila et al., 1998).

The predictive in vitro assay is advantageous in terms of providing useful ways to prioritize screening and reduce the assay requirements. It also offers a clear, next step in exploring the biological effects of a compound. In vitro assays are less complex in the number of factors that would influence a positive readout, making the successful development of an in silico model more likely (Greene and Naven, 2009).

The contradicting results obtained so far with gallates indicate that the knowledge of the effects (beneficial or adverse) has largely remained elusive. With an aim to ensure public safety, the present study assessed alkyl gallates for their cytotoxicity and proapoptotic activities, as well as their genotoxic and mutagenic potential. Further, the chemopreventive activity of alkyl gallates on DNA damage induced by $\mathrm{H}_{2} \mathrm{O}_{2}$ (a direct-acting mutagen) was investigated. The results of the present study would add beneficial data to the knowledge of alkyl gallates as non-genotoxic, nonmutagenic, pro-apoptotic, and suitable agents for preventing various types of cancer.

\section{Methodology}

\subsection{Chemicals}

Alkyl gallates with side chains varying from five to eight carbons (pentyl, hexyl, heptyl, and octyl gallates) were synthesized as described by (Silva et al., 2013).

\subsection{Cell culture}

The following cell lines were used in the study: HepG2; human liver carcinoma cell line (ATCC, HB8065), DU-145; human prostate cancer cell line (ATCC, HTB-81), MDA-MB-231; human breast carcinoma cell line (ATCC, HTB-26), MRC-5; human lung fibroblast cell line (ATCC, CCL-171), and A549; human lung adenocarcinoma epithelial cell line (ATCC, CCL-185). The cell lines were obtained from the American Type Culture Collection (ATCC) (Manassas, VA, USA) and grown in DMEM or Ham's F10 (A549 cell line) medium supplemented with $10 \% \mathrm{FBS}, 1 \%$ penicillin $(100 \mathrm{U} / \mathrm{mL})$, and streptomycin $(100 \mu \mathrm{g} / \mathrm{mL})$. The cells were maintained in a humidified environment at $37{ }^{\circ} \mathrm{C}$ with $5 \% \mathrm{CO}_{2}$ and sub-cultured twice per week. The viability of the cells was checked before conducting the experiments. In brief, a freshly prepared solution of Trypan blue $(0.05 \%, 10 \mu \mathrm{L})$ in distilled water was mixed with $10 \mu \mathrm{L}$ of cellular suspension for $5 \mathrm{~min}$, spread onto a microscope slide and covered with a coverslip. The non-viable cells appeared blue under the microscope.

\subsection{Cytotoxicity tests}

The cytotoxicity was measured fluorometrically by the resazurin reduction assay. Resazurin is a non-toxic and non-fluorescent blue reagent that is irreversibly reduced to a fluorescent and pinkcolored resorufin by the viable cells undergoing active metabolism. Nonviable cells rapidly lose the metabolic capacity to reduce resazurin and thus do not produce a fluorescent signal. Therefore, resazurin serves as a cell permeable redox indicator for monitoring the number of viable cells.

For the resazurin reduction assay, $2.5 \times 10^{4}$ cells/well were seeded into a 96-well cell culture plate $\left(\operatorname{Costar}^{\circledR}{ }^{\circledR}\right.$, Cambridge, MA, USA) in a total volume of $100 \mu \mathrm{L}$ for $24 \mathrm{~h}$. The cells were then treated with the following alkyl gallates: pentyl, hexyl, heptyl, and octyl gallates at concentrations ranging from 1.6 to $200 \mu \mathrm{g} / \mathrm{mL}$. After $24 \mathrm{~h}$ incubation, the medium was removed, and $50 \mu \mathrm{L}$ of resazurin (Sigma-Aldrich $^{\circledR}$, St. Louis, MO, USA) prepared in $0.01 \% \mathrm{w} / \mathrm{v}$ of DMEM was added to each well, and the plates were incubated at $37^{\circ} \mathrm{C}$ for $3 \mathrm{~h}$. The fluorescence was measured on Synergy H1 microplate reader $\left(\right.$ BioTek $^{\mathbb{R}}$, Winooski, VT, USA) using an excitation wavelength of $530 \mathrm{~nm}$ and an emission wavelength of $590 \mathrm{~nm}$. The untreated cells constituted the negative control (viable cells), whereas those treated with $1 \%$ dimethyl sulfoxide (DMSO) and $5 \mu \mathrm{g} / \mathrm{mL}$ of doxorubicin (Sigma-Aldrich ${ }^{\circledR}$, St. Louis, MO, USA) constituted the vehicle and positive controls (dead cells), respectively. Three independents assays were performed. The $\mathrm{IC}_{50}$ value that represents the sample concentration required to inhibit $50 \%$ of cell proliferation was calculated from a calibration curve by regression analysis.

\subsection{Detection of apoptosis}

Nuclear morphology was assessed by staining the cells with Hoechst 33342 and propidium iodide (PI). HepG2 cells were cultured at a density of $2.5 \times 10^{4}$ cells/well in a 96-well plate followed by incubation in the culture medium for $24 \mathrm{~h}$ at $37^{\circ} \mathrm{C}$ with $5 \% \mathrm{CO}_{2}$. The culture medium was replaced with $100 \mu \mathrm{L}$ of medium containing the $\mathrm{IC}_{50}$ concentration of the alkyl gallates (pentyl, hexyl, heptyl, and octyl gallates) previously determined by the resazurin reduction assay and incubated for $24 \mathrm{~h}$. The untreated cells, $1 \%$ DMSO, and $0.5 \mu \mathrm{g} / \mathrm{mL}$ of doxorubicin were utilized as negative, vehicle, and positive controls, respectively. To stain the DNA, the cells were incubated with Hoechst $33342(10 \mu \mathrm{M})$ and PI $(10 \mu \mathrm{M})$ diluted in phosphate-buffered saline (PBS) for $10 \mathrm{~min}$ at room temperature. The cells were then observed by the IN Cell Analyzer 1000 (GE Healthcare ${ }^{\circledR}$, USA). Based on the staining and the level of DNA condensation, the nuclei were categorized into four types, namely intact blue nuclei, condensed/fragmented blue nuclei, condensed/fragmented pink nuclei, and intact pink nuclei. These categories corresponded to viable, early apoptotic, late apoptotic, and necrotic cells, respectively. A total of 500 cells were counted, and the percentage of viable, apoptotic, and necrotic cells was calculated. The results were expressed as the mean \pm standard 
error of three independent experiments performed in duplicate (Hashimoto et al., 2003).

\subsection{Single cell gel electrophoresis assay (comet assay)}

For the comet assay, HepG2 cells were seeded into 24-well plates at an initial concentration of $2.5 \times 10^{4}$ cells/well and treated with the alkyl gallates (pentyl, hexyl, heptyl, and octyl gallates) at $\mathrm{IC}_{30}$ for $24 \mathrm{~h}$. The positive and negative controls used were medium with and without $\mathrm{H}_{2} \mathrm{O}_{2}(1 \mathrm{mM})$, respectively, for $5 \mathrm{~min}$. In addition, a vehicle control (0.01\% DMSO, which was the maximum concentration of solvent used in the test) was included. The comet assay was performed by following the protocol of (Tice et al., 2000). Briefly, $20 \mu \mathrm{L}$ of cells was mixed with $120 \mu \mathrm{L}$ of $0.5 \%$ low-melting-point agarose at $37{ }^{\circ} \mathrm{C}$. It was layered onto a precoated slide with $1.5 \%$ regular agarose and covered with a coverslip. After the solidification of agarose at $4{ }^{\circ} \mathrm{C}$, the coverslip was removed, and the slides were immersed in the cold lysing solution $(2.5 \mathrm{M} \mathrm{NaCl}$, $100 \mathrm{mM}$ EDTA, $10 \mathrm{mM}$ Tris-HCl buffer, pH 10.0, 1\% sodium sarcosinate with $1 \%$ triton X-100 and 10\% DMSO) for $24 \mathrm{~h}$. After lysis, the slides were exposed to an alkaline buffer $(\mathrm{pH}>13.0)$ for $20 \mathrm{~min}$ (to unwind the DNA) and subjected to electrophoresis for $20 \mathrm{~min}(25 \mathrm{~V}$, $300 \mathrm{~mA}$ ). Then, the slides were neutralized with $0.4 \mathrm{M}$ Tris- $\mathrm{HCl}$ buffer ( $\mathrm{pH}$ 7.5) for $15 \mathrm{~min}$, fixed in absolute ethanol and stored at $4{ }^{\circ} \mathrm{C}$ until analysis. Duplicate slides were stained with SYBR ${ }^{\circledR}$ Green, (Sigma-Aldrich ${ }^{\circledR}$, St. Louis, MO, USA) and 50 randomly selected pretreated cells (wells) were examined at $400 \times$ magnification on a fluorescence microscope. The images were analyzed using TriTeK CometScore $^{\mathrm{TM}}$ software image analysis system (TriTek Corp., Sumerduck, VA, USA).Tail moment (product of tail DNA/total DNA by the tail center of gravity) in arbitrary units was selected as an indicator of DNA damage, and the percentage of DNA in the tail (percentage DNA) was calculated. The results were expressed as the mean \pm standard error of three independent experiments performed in duplicate.

\subsection{Cytokinesis-block micronucleus cytome (CBMN) assay}

The CBMN assay was performed according to the Organization for Economic Co-operation and Development (OECD) Guidelines (OECD, 2010). CBMN is considered to be the method of choice for analyzing DNA damage, cytostasis, and cytotoxicity. Formation of micronuclei is regarded as the hallmark of chromosome breakage (DNA damage); the assay helps to determine the proportion of mono-, bi-, tri-, and tetra-nucleated cells.

\subsubsection{Mutagenic evaluation}

HepG2 cells at a density of $2 \times 10^{4}$ cells/well were seeded into 96 -well cell culture plates. Twenty-four hour after seeding, the medium was removed, and the cells were treated with the alkyl gallates in three concentrations below the $\mathrm{IC}_{30}$ (previously determined by resazurin reduction assay) for $24 \mathrm{~h}$. The controls included cells without treatment (negative control); $1 \mathrm{mM} \mathrm{H}_{2} \mathrm{O}_{2}$ (positive control, treated for $5 \mathrm{~min}$ ) and 1\% DMSO (vehicle control). Then, the cells were washed twice with PBS and incubated with the medium containing $6 \mu \mathrm{g} / \mathrm{mL}$ of cytochalasin B (Sigma-Aldrich ${ }^{\circledR}$, St. Louis, MO, USA) for $48 \mathrm{~h}$.

\subsubsection{Antimutagenic evaluation (chemopreventive potential)}

Twenty-four hour after seeding, the medium was removed, and the cells were treated with the alkyl gallates at three concentrations below the $\mathrm{IC}_{30}$ for $24 \mathrm{~h}$. Then, the cells were washed with PBS and treated with $\mathrm{H}_{2} \mathrm{O}_{2}(1 \mathrm{mM})$ for $5 \mathrm{~min}$. The cells were then washed twice with PBS, and incubated with the medium containing cytochalasin B at a concentration of $6 \mu \mathrm{g} / \mathrm{mL}$ for $48 \mathrm{~h}$.
For both mutagenic and antimutagenic evaluations, the medium was removed, and the cells were fixed using $100 \mu \mathrm{L}$ of absolute ethanol for $30 \mathrm{~min}$ at room temperature. After fixation and washing with PBS, the cells were incubated with $100 \mu \mathrm{L}$ of FITC per well (Sigma-Aldrich ${ }^{\circledR}$, St. Louis, MO, USA) for $30 \mathrm{~min}$ at room temperature. FITC solution was prepared from a $10 \mathrm{mg} / \mathrm{mL}$ stock solution of FITC in DMSO; $10 \mu \mathrm{L}$ of it was diluted in $100 \mathrm{~mL}$ of PBS). The cells were washed thrice and stained with Hoechst 33342 solution $(5 \mu \mathrm{M}$ in PBS) for 15 min (Sigma-Aldrich ${ }^{\circledR}$, St. Louis, MO, USA). Imaging was performed by IN Cell Analyzer 2000 (GE Healthcare ${ }^{\circledR}$, Little Chalfont, UK) using the following filters: excitation $352 \mathrm{~nm}$ (Hoechst 33342) and $495 \mathrm{~nm}$ (FITC), and emission: $461 \mathrm{~nm}$ (Hoechst 33342) and $521 \mathrm{~nm}$ (FITC). A 20×, wide-field objective was used to acquire the images. For all conditions, ten fields per well were imaged to reach the minimum count of 500 binuclear cells (1000 per concentration) needed for the analysis. The nuclear division index (NDI), a marker of cell proliferation was estimated by scoring 500 cells with one to four nuclei. The NDI was calculated using the formula [M1 + 2M2 + 3M3 + M4]/500, where M1, M2, M3, and M4 represent the number of cells with one to four nuclei, respectively. The NDI provides a measure of the proliferative status of the viable cell fraction and serves as an indicator of cytostatic effects. The lowest possible value of NDI is 1.0, which occurs if all of the viable cells have failed to divide during the cytokinesis-block and are therefore all mononucleated. Successful completion of one nuclear division of viable cells results in binucleated cells, and the NDI value is 2.0 (Fenech, 2007). The results were expressed as the mean \pm standard error of three independent experiments performed in duplicate.

\subsection{Statistical analysis}

All statistical analyses were performed using GraphPad Prism version 5.00 (GraphPad, San Diego, CA, USA). The data were analyzed using one-way or two-way analysis of variance (ANOVA) followed by Tukey's post-test or Bonferroni's post hoc test (apoptosis test) as required. The probability values of less than the significance level (alpha $=0.05, P<0.05$ ) were considered statistically significant in two-tailed tests.

\section{Results and discussion}

Gallic acid (3,4,5-trihydroxybenzoic acid) is an organic acid and a naturally occurring polyhydroxy phenolic compound abundantly present in various fruits and vegetables. The compound is widely employed to cure various disorders owing to its antiproliferative, antibacterial, antifungal, antiviral, and antioxidant activities (Aruoma et al., 1993; Fujita and Kubo, 2002; Kubo et al., 2004; Dodo et al., 2008; Kratz et al., 2008; Merkl et al., 2010). However, contradictory results exist in the literature regarding its toxicological safety levels. While some authors suggest that they are safe to be used as chemopreventive compounds due to their selective toxicity for tumor cells thereby diminishing the tumor growth (Feng et al., 2003; Galati and O'Brien, 2004; Pandır, 2015), others demonstrate a genotoxic or mutagenic effect in the form of chromosomal aberrations (Tayama and Nakagawa, 2001; Furukawa et al., 2003; Savi et al., 2005).

In order to further assure the safety and biological effects of gallic acid derivatives, in the present study, we carried out an in vitro risk assessment of semi-synthetic esters of gallic acid. A series of alkyl gallates with side chains varying from five to eight carbons (pentyl, hexyl, heptyl, and octyl gallates) were evaluated for their cytotoxic and pro-apoptotic potential. In addition, the genotoxic effects of alkyl gallates were measured in HepG2 cells using the single-cell gel electrophoresis (SCGE) assay (comet assay) 
and the cytokinesis-blocked micronucleus (CBMN) test.

\subsection{Cytotoxic potential of alkyl gallates}

The gallic acid ester derivatives exhibited a cytotoxic effect on four human tumor cell lines (HepG2, DU-145, A549, and MDA-MB231 ) and one human normal cell line (MRC-5) in a concentrationdependent manner (Table 1). The cell lines DU-145 and MRC-5 were observed to be the most sensitive to the compounds with $\mathrm{IC}_{50}$ values ranging from 37 to $90 \mu \mathrm{g} / \mathrm{mL}$ and $12-75 \mu \mathrm{g} / \mathrm{mL}$ for DU145 and MRC-5, respectively.

The apparently high resistance of the human hepatoma cell line, HepG2 toward alkyl gallates could be related to its metabolizing potential that mimics the metabolic status of human liver cells. The drug metabolizing capability of HepG2 cells interferes with the cytotoxicity of heptyl and octyl gallates, which is reflected by the expression of various phase I and phase II enzymes of the liver that play a crucial role in the activation and detoxification of various genotoxic procarcinogens. Therefore, HepG2 cells serve as a promising in-vivo system for a better evaluation of the metabolism of such compounds than the experimental models that suffer from the limitation of use of metabolically incompetent cells and exogenous activation mixtures (Knasmuller et al., 1998).

Another possible mechanism that has recently emerged to be responsible for the induction of chemoresistance is the modulation of the transcription nuclear factor, erythroid 2 (NF-E2) p45-related factor-2 (Nrf2) (Wang et al., 2008; Geismann et al., 2014; Furfaro et al., 2016). Under normal physiological conditions, Nrf2 serves as an essential transcription factor for various antioxidant and detoxification genes, thereby providing protection to normal cells against oxidative and xenobiotic damage (Kansanen et al., 2013). Nrf2 inhibitors act as crucial molecules for the chemopreventive effect of various phytochemicals against carcinogenesis (No et al., 2014; Wang et al., 2008) demonstrated that upregulation of Nrf2 enhanced the cell resistance in lung carcinoma (A549), breast adenocarcinoma (MDA-MB-231), and neuroblastoma (SH-SY5Y) cells. Recent reports provide evidence that the treatment with epigallocatechin-3-gallate (EGCG), a major flavonoid in green tea upregulates Nrf2 (Wu et al., 2006; Na and Surh, 2008; Zheng et al., 2012). Furthermore (Kweon et al., 2006), demonstrated that resistance to EGCG induced apoptosis in A549 cells is conferred by Nrf2mediated $\mathrm{HO}-1$ overexpression.

Accordingly to Inoue et al., 1995 cytotoxicity is not a feature common to phenolic compounds. However, it is a characteristic attribute of gallic acid, where the three adjacent phenolic hydroxyl groups are responsible for the cytotoxicity. On the other hand, gallates with long alkyl groups bound to the carboxyl group in the gallic acid moiety have been found to be toxic to rat hepatocytes although at a higher concentration than that observed for tumor cells. It seems that mitochondrial respiration is a common target of these compounds. In isolated rat liver mitochondria, gallates are known to cause a concentration-dependent increase in the oxygen consumption rate indicating toward a partial uncoupling of

\section{Table 1}

Cytotoxic activity $\left(\mathrm{IC}_{50}\right.$ values $^{\mathrm{a}}$ ) of alkyl gallates against HepG2, DU-145, A549, MDAMB-231, and MRC-5 cell lines.

\begin{tabular}{llllll}
\hline \multicolumn{6}{l}{ Cytotoxic activity $\left(\mathrm{IC}_{50}\right)$ in $\mu \mathrm{g} \mathrm{mL}^{-1}$} \\
\hline Substances & HepG2 & DU-145 & A549 & MDAMB-231 & MRC-5 \\
\hline pentyl gallate & 200 & 90 & 150 & 190 & 75 \\
hexyl gallate & 145 & 65 & 105 & 125 & 42 \\
heptyl gallate & 42 & 55 & 96 & 130 & 17 \\
octyl gallate & 30 & 37 & 57 & 70 & 12 \\
\hline
\end{tabular}

${ }^{\mathrm{a}} \mathrm{IC}_{50}$ - concentration required to inhibit $50 \%$ of cell growth. respiration (Nakagawa et al., 1995; Nakagawa and Tayama, 1995; Nakagawa et al., 1996).

Among the gallates analyzed in different cell lines, octyl gallate was observed to be the most cytotoxic compound with an $\mathrm{IC}_{50}$ value ranging from 12 to $70 \mu \mathrm{g} / \mathrm{mL}$. It is possible that the observed differences between these molecules may be due to the variations in the cytotoxic potential, which in turn is related to the length of the lipophilic alkyl side chain. Thus, the length of the lipophilic alkyl side chain may exert a strong impact on the membrane affinity of these compounds, a hypothesis that is in agreement with other studies on alkyl gallates (Feng et al., 2003; Tammela et al., 2004; Locatelli et al., 2008).

\subsection{Cell death evaluation}

Apoptosis plays an important role in the regulation of cell number during development and tissue homeostasis (Kiechle and Zhang, 2002). As an efficient pathway of cellular death, therapies based on apoptosis-inducers are highly desirable for lowering the associated toxic side-effects of using chemotherapeutics in the prevention of cancer (Taraphdar et al., 2001, Fischer and SchulzeOsthoff, 2005).

Fig. 1 demonstrates a representative image of HepG2 cells double-stained with Hoechst 33342 and PI. Fig. 2 shows the percentage of viable, early apoptotic, late apoptotic, and necrotic HepG2 cells after treatment with alkyl gallates at $\mathrm{IC}_{50}$. All treatments significantly induced the early apoptotic pathway as compared with the control without treatment $(p<0.05)$. No differences were observed when the cells were compared with those treated with doxorubicin, an antitumoral used as a reference drug. Besides, doxorubicin induced a higher amount of late apoptotic death in comparison to the alkyl gallates. Based on the morphological characterization of the cells, we conclude that the induced cytotoxic effects were an outcome of induction of apoptosis.

Our data are in accordance with other studies that have shown that gallic acid and its derivatives act as effective inducers of apoptosis in different cell lines (Serrano et al., 1998; Roy et al., 2000; Saeki et al., 2000; Dodo et al., 2008; Locatelli et al., 2009).

Studies have shown that gallates with up to eight carbons in the alkyl chain can be absorbed; however, gallates with more than eight carbons are poor absorbents (Tammela et al., 2004). The absorbed gallates are metabolized by intracellular esterases and promote free radical generation, thereby activating the intrinsic pathway of apoptosis (Hsu et al., 2007; Locatelli et al., 2009).

(Isuzugawa et al., 2001) suggested that alkyl gallates promote changes in the intracellular $\mathrm{Ca}^{2+}$ levels and the effect was related to the generation of secondary reactive oxygen species (ROS) and initiation of apoptosis. Moreover, caspase-3 activation was related to the intracellular $\mathrm{Ca}^{2+}$ increase, which triggers the initiation of mitochondrial permeability transition (MPT) culminating in the release of cytochrome $c$ into the cytoplasm through a mitochondrial permeability transition pore (MPTP). Thereafter, cytochrome $c$ activates pro-caspase- 9 and an upstream caspase, particularly caspase-3, in combination with apoptotic peptidase activating factor-1 (Apaf-1) followed by the activation of downstream caspases to orchestrate the various biochemical processes.

\subsection{Genotoxic evaluation of alkyl gallates}

The comet assay (single cell gel electrophoresis) is considered as the method of choice for measuring DNA damage in eukaryotic cells or disaggregated tissues due to its rapid, non-invasive, and sensitive nature. The working principle of the assay is based on the relaxation of supercoiled DNA within the agarose-embedded nucleoids (residual bodies formed after lysis of cells with the detergent and 

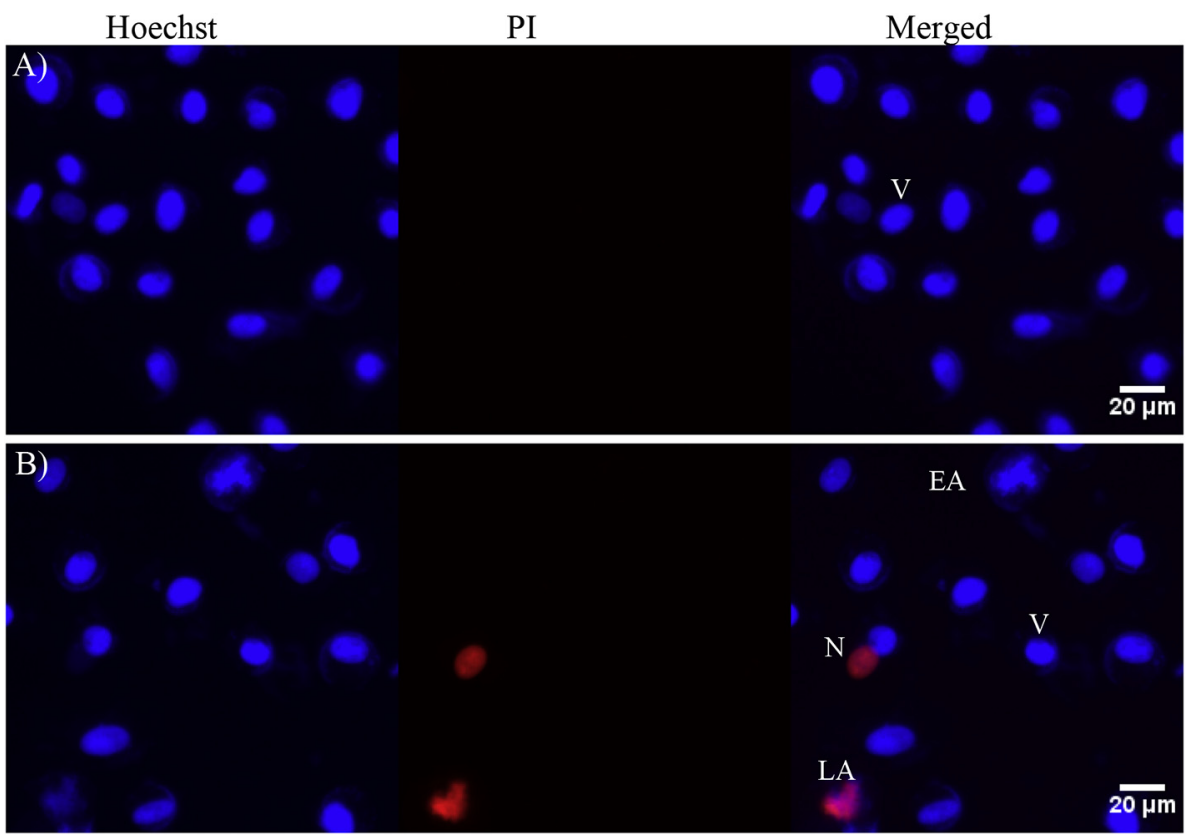

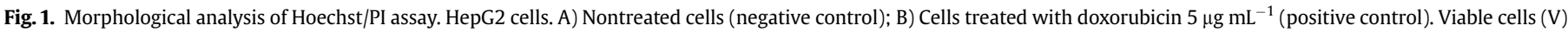
Early Apoptosis (EA). Late Apoptosis (LA) and Necrotic cells (N). Photomicrographs were taken at 200× magnification.

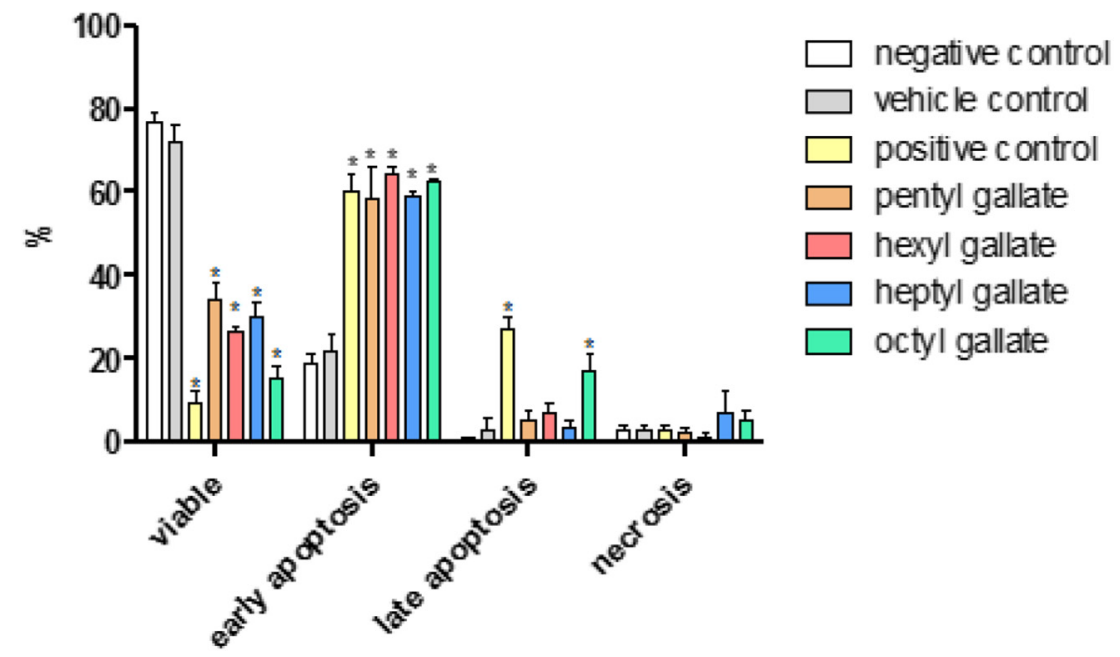

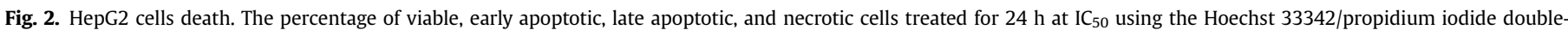

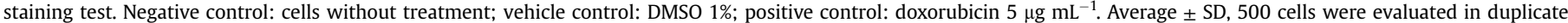

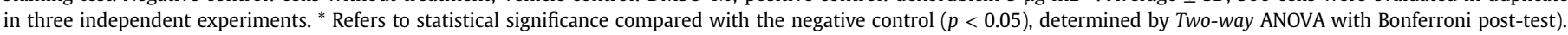

high salts). This causes the DNA to stretch out toward the anode under electrophoresis leading to the generation of comet-like images as observed under the fluorescence microscopy. The relative amount of DNA in the comet tail is indicative of the frequency of DNA breaks (Azqueta and Collins, 2013). The HepG2 cell line was selected to perform genotoxicity and mutagenic assays due to its characteristics, such as endogenous bioactivation capacity, retention of many of the morphological features of liver parenchymal cells, and the presence of several enzymes responsible for the activation of various xenobiotics (Uhl et al., 2000). Fig. 3 depicts a representative image of the undamaged $\mathrm{HepG} 2$ cells using $\mathrm{H}_{2} \mathrm{O}_{2}$ that induces comet formation (positive control) along with a negative control. The results derived from the treatments with the four compounds at $\mathrm{IC}_{30}$ (non-cytotoxic concentration) indicated no significant genotoxic effects (Fig. 4) compared with the negative control $(p<0.05)$. In addition, the vehicle control did not display any differences with respect to the negative control confirming no adverse biological effects at low concentrations ( $1 \%)$ of DMSO.

\subsection{Mutagenic and chemopreventive evaluation of alkyl gallates}

The micronucleus assays have emerged as one of the preferred methods for assessing chromosomal damage due to their ability to measure reliably both chromosomal loss as well as chromosomal breakage (Fenech, 2000). Moreover, it is considered as a useful endpoint for the evaluation of chromosomal damage in vitro and in vivo caused by different mutagens (Garaj-Vrhovac et al., 2008). Micronuclei (MNi) originate from whole chromosomes or chromosomal fragments that lag behind at anaphase during nuclear division. These are morphologically identical to but smaller than 
A)

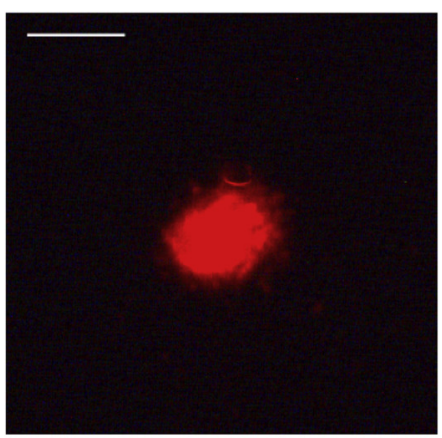

B)

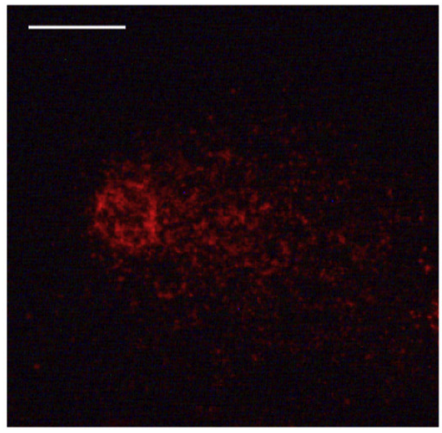

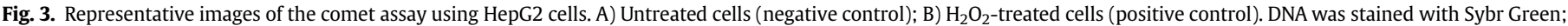
$400 \times$ magnification. Scale bar $20 \mu \mathrm{m}$. (For interpretation of the references to colour in this figure legend, the reader is referred to the web version of this article.)

A)

Tail Moment

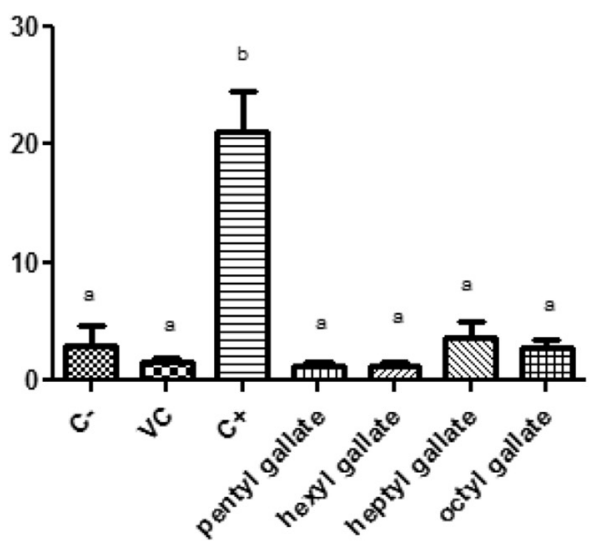

B)

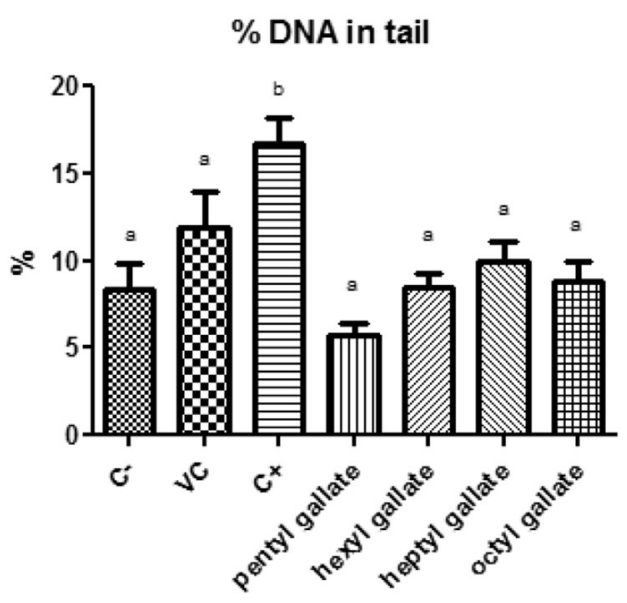

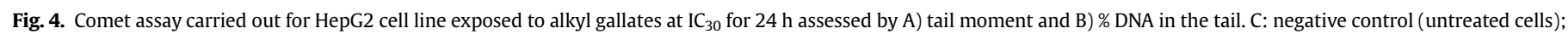

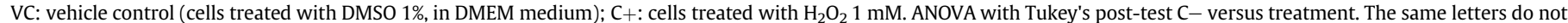

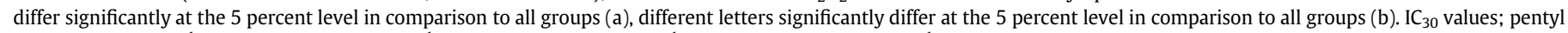
gallate: $125 \mu \mathrm{g} \mathrm{mL}^{-1}$; hexyl gallate: $30 \mu \mathrm{g} \mathrm{mL}^{-1}$; heptyl gallate: $10 \mu \mathrm{g} \mathrm{mL}{ }^{-1}$ and octyl gallate: $1 \mu \mathrm{g} \mathrm{mL}^{-1}$.

the nucleus with the diameter varying between $1 / 16$ th and $1 / 3$ rd of the mean diameter of the main nucleus (Fenech, 2007) (Fig. 5).

In the present study, micronucleus formation was evaluated in HepG2 cells treated with alkyl gallates at several concentrations below the $\mathrm{IC}_{30}$ (Table 2). The data obtained clearly demonstrate that the selected doses could not induce significant MNi formation as compared to the MNi level in the untreated cells. The substances also did not affect the cell division, whereas the positive control $\left(\mathrm{H}_{2} \mathrm{O}_{2}\right)$ significantly decreased the nuclear division index (NDI).

Alkyl gallates, mainly propyl and octyl gallates, are widely used

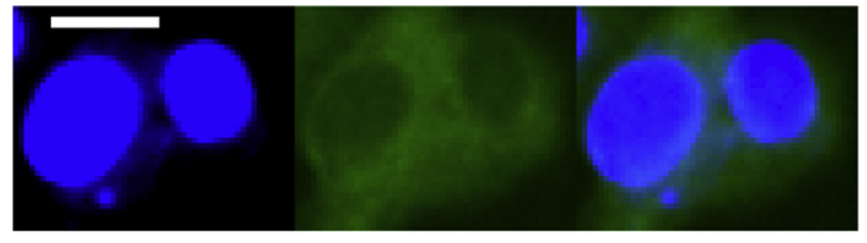

Hoechst

FITC

Merged

Fig. 5. A representative image of a binucleated cell with micronucleus. Hoechst 33342/ FITC staining; Scale bar $20 \mu \mathrm{m}$. as food antioxidants (Gulati et al., 1989). reported that propyl gallate at dose levels of $5-50 \mu \mathrm{g} / \mathrm{mL}$ significantly induced chromosomal aberrations and sister chromatid exchange in Chinese hamster ovary (CHO) cells but only in the absence of metabolic activation and with extended harvest times. However, no information regarding the cytotoxicity level was provided. Similarly (Fowler et al., 2012), demonstrated that the metabolizing capacity of HepG2 plays a pivotal role in the detoxification of alkyl gallates.

The chemopreventive potential of alkyl gallates was also evaluated through CBMN assay. In this assay, the cells previously treated with the alkyl gallates for $24 \mathrm{~h}$ were submitted to $\mathrm{H}_{2} \mathrm{O}_{2}$ exposure. All substances could significantly protect HepG2 cells against mutagenic damage induced by $\mathrm{H}_{2} \mathrm{O}_{2}$ in comparison to the untreated but $\mathrm{H}_{2} \mathrm{O}_{2}$ exposed cells (positive control) (Table 3 ) at $\mathrm{IC}_{30}$ concentrations. Our results are in accordance with other studies that have reported gallic acid and its derivatives as anti-genotoxic/ anti-mutagenic and hepatoprotective agents providing cellular protection against oxidative DNA damage (Feng et al., 2003; Morley et al., 2005; Glei and Pool-Zobel, 2006; Pandır, 2015).

The modes of action of antimutagenic and anticarcinogenic nature of gallates, especially EGCG have been extensively studied, and many different mechanisms have been proposed (Lo and Stich, 
Table 2

Assessment of mutagenic effects of alkyl gallates on HepG2 cells using the cytokinesis-block micronucleus cytome assay (CBMN-cyt).

\begin{tabular}{lll}
\hline Treatments & MNi & NDI \\
\hline Vehicle & $23.3 \pm 6.1$ & $1.78 \pm 0.04$ \\
Negative & $28.3 \pm 4.5$ & $1.77 \pm 0.03$ \\
Positive & $103 \pm 20^{\mathrm{b}^{* * * *}}$ & $1.59 \pm 0.03^{* * *}$ \\
& & \\
pentyl gallate & & \\
$125 \mu \mathrm{g} \mathrm{mL}^{-1}$ & $24 \pm 8.2$ & $1.68 \pm 0.12$ \\
$62.5 \mu \mathrm{g} \mathrm{mL}^{-1}$ & $26 \pm 4.6$ & $1.75 \pm 0.05$ \\
$31.3 \mu \mathrm{g} \mathrm{mL}^{-1}$ & $17.7 \pm 5.5$ & $1.76 \pm 0.06$ \\
& & \\
hexyl gallate & & $1.72 \pm 0.05$ \\
$30 \mu \mathrm{g} \mathrm{mL}^{-1}$ & $40 \pm 5.3$ & $1.71 \pm 0.09$ \\
$15 \mu \mathrm{g} \mathrm{mL}^{-1}$ & $32.7 \pm 9.7$ & $1.73 \pm 0.05$ \\
$7.5 \mu \mathrm{g} \mathrm{mL}^{-1}$ & $24 \pm 2.65$ & \\
& & $1.67 \pm 0.08$ \\
heptyl gallate & & $1.72 \pm 0.08$ \\
$10 \mu \mathrm{g} \mathrm{mL}^{-1}$ & $36 \pm 2.6$ & $1.77 \pm 0.03$ \\
$5 \mu \mathrm{g} \mathrm{mL}$ & \\
$2.5 \mu \mathrm{g} \mathrm{mL}^{-1}$ & $22 \pm 3$ & $1.59 \pm 0.03$ \\
octyl gallate $_{1 \mu \mathrm{gL}^{-1}}$ & $21.3 \pm 11.9$ & $1.76 \pm 0.04$ \\
$0.5 \mu \mathrm{g} \mathrm{mL}^{-1}$ & & $1.75 \pm 0.03$ \\
$0.2 \mu \mathrm{g} \mathrm{mL}^{-1}$ & $35.5 \pm 5$ & \\
\hline
\end{tabular}

Values shown are the mean $\pm \mathrm{SD}$; BN: binucleated cell; MNi: micronuclei; NDI: nuclear division index. The data shown are based on three independent experiments. The cells were treated with three concentrations below $\mathrm{IC}_{30}$ values, Vehicle control: 1.0\% DMSO; Negative control: Untreated cells; Positive control, Cells treated with $\mathrm{H}_{2} \mathrm{O}_{2} ; 1 \mathrm{mM}$. One-way ANOVA with Tukey's post-test. Significant differences between treated cells and the negative group are indicated by ${ }^{* * *} P<0.001$.

Table 3

Assessment of chemoprotective effects of alkyl gallates on HepG2 cells using the cytokinesis-block micronucleus cytome assay (CBMN-cyt).

\begin{tabular}{|c|c|c|}
\hline Treatments & MNs & NDI \\
\hline Vehicle & $29.2 \pm 4.8^{* * *}$ & $1.8 \pm 0.07$ \\
\hline Negative & $28.7 \pm 6.2^{* * *}$ & $1.8 \pm 0.05$ \\
\hline Positive & $109 \pm 12.2$ & $1.59 \pm 0.09$ \\
\hline \multicolumn{3}{|l|}{ pentyl gallate } \\
\hline $125 \mu \mathrm{g} \mathrm{mL}^{-1}$ & $67 \pm 8.6^{* * *}$ & $1.76 \pm 0.09$ \\
\hline $62.5 \mu \mathrm{g} \mathrm{mL}^{-1}$ & $70 \pm 12.2^{* *}$ & $1.77 \pm 0.08$ \\
\hline $31.3 \mu \mathrm{g} \mathrm{mL}^{-1}$ & $93.3 \pm 6.4$ & $1.73 \pm 0.05$ \\
\hline \multicolumn{3}{|l|}{ hexyl gallate } \\
\hline $30 \mu \mathrm{g} \mathrm{mL}^{-1}$ & $66.2 \pm 6.7^{* * *}$ & $1.76 \pm 0.06$ \\
\hline $15 \mu \mathrm{g} \mathrm{mL}^{-1}$ & $80 \pm 12.9^{* *}$ & $1.75 \pm 0.06$ \\
\hline $7.5 \mu \mathrm{g} \mathrm{mL}^{-1}$ & $84.8 \pm 7.1$ & $1.72 \pm 0.05$ \\
\hline \multicolumn{3}{|l|}{ heptyl gallate } \\
\hline $10 \mu \mathrm{g} \mathrm{mL}^{-1}$ & $81 \pm 3.1^{* * *}$ & $1.68 \pm 0.07$ \\
\hline $5 \mu \mathrm{g} \mathrm{mL}^{-1}$ & $91.7 \pm 12.3^{*}$ & $1.74 \pm 0.06$ \\
\hline $2.5 \mu \mathrm{g} \mathrm{mL}^{-1}$ & $96.5 \pm 7.1$ & $1.68 \pm 0.09$ \\
\hline \multicolumn{3}{|l|}{ octyl gallate } \\
\hline $1 \mu \mathrm{g} \mathrm{mL}^{-1}$ & $83 \pm 12.1^{*}$ & $1.69 \pm 0.05$ \\
\hline $0.5 \mu \mathrm{g} \mathrm{mL}^{-1}$ & $93.2 \pm 9.6$ & $1.72 \pm 0.06$ \\
\hline $0.2 \mu \mathrm{g} \mathrm{mL}^{-1}$ & $104 \pm 13$ & $1.7 \pm 0.05$ \\
\hline
\end{tabular}

Values shown are the mean $\pm \mathrm{SD}$; BN: binucleated cell; MNi: micronuclei; NDI: nuclear division index. The data shown are based on three independent experiments. The cells were treated with three concentrations below $\mathrm{IC}_{30}$. Vehicle control, 1.0\% DMSO; Negative control: Untreated cells; Positive control, Cells treated only with $\mathrm{H}_{2} \mathrm{O}_{2} ; 1 \mathrm{mM}$. One-way ANOVA with Tukey's post-test. Significant differences between treated cells and the positive group are indicated by ${ }^{*} P<0.05$, ${ }^{* *} P<0.01$ and ${ }^{* * *} P<0.001$.

1978). suggested that antioxidants may act as antimutagens by preventing the formation of reactive carcinogens or by competing with proximate carcinogens or mutagens. (Hour et al., 1999), who studied the antimutagenic properties of gallic acid, demonstrated that the compound could scavenge electrophilic mutagens. Therefore, they suggested that gallic acid-based compounds could bind to or insert into the outer membrane of the cell transporters leading to the blockage of a mutagen that gets finally transferred into the cytosol. However, further studies need to be performed to address the question.

\section{Conclusion}

In summary, our results provide a significant risk assessment of the alkyl gallates including in vitro evidence of the non-genotoxic and non-mutagenic nature of these substances, thereby ruling out their potentially hazardous nature for human health as reported by other researchers.

Furthermore, the present study also demonstrates that alkyl gallates not only have a chemopreventive effect against HepG2 but may also eliminate cancer cells through induction of apoptosis. Therefore, alkyl gallates could be used as a putative therapeutic target for the prevention of the occurrence of some types of cancer. Nevertheless, the potential risks and beneficial effects of alkyl gallates should be confirmed further by in vivo approaches.

\section{Conflict of interest}

The authors declare that there are no conflicts of interest.

\section{Acknowledgements}

ICS received a postdoctoral fellowship from FAPESP (2013/ 24449-7). CRP and LAA received scholarships from CAPES and CNPq, respectively. This work was supported by the São Paulo Research Foundation, FAPESP, grant 2013/50367- 8 to HF.

\section{Transparency document}

Transparency document related to this article can be found online at http://dx.doi.org/10.1016/j.fct.2017.04.033.

\section{References}

Aruoma, O.I., Murcia, A., Butler, J., Halliwelt, B., 1993. Evaluation of the antioxidan and prooxidant actions of gallic acid and its derivatives. J. Agric. Food \& Chem. 41, 1880-1885.

Azqueta, A., Collins, A.R., 2013. The essential comet assay: a comprehensive guide to measuring DNA damage and repair. Arch. Toxicol. 87 (6), 949-968.

Bagchi, D., Swaroop, A., Preuss, H.G., Bagchi, M., 2014. Free radical scavenging, antioxidant and cancer chemoprevention by grape seed proanthocyanidin: an overview. Mutat. Research/Fundamental Mol. Mech. Mutagen. 768, 69-73.

Davila, J.C., Rodriguez, R.J., Melchert, R.B., Acosta Jr., D., 1998. Predictive value of in vitro model systems in toxicology. Annu. Rev. Pharmacol. Toxicol. 38, 63-96.

Dodo, K., Minato, T., Noguchi-Yachide, T., Suganuma, M., Hashimoto, Y., 2008. Antiproliferative and apoptosis-inducing activities of alkyl gallate and gallamide derivatives related to (-)-epigallocatechin gallate. Bioorg Med. Chem. 16 (17), 7975-7982. Epub 2008 Jul 7929.

Fenech, M., 2000. The in vitro micronucleus technique. Mutat. Res. 455 (1-2), 81-95.

Fenech, M., 2007. Cytokinesis-block micronucleus cytome assay. Nat. Protoc. 2 (5), 1084-1104.

Feng, Q., Kumagai, T., Nakamura, Y., Uchida, K., Osawa, T., 2003. Correlation of antimutagenic activity and suppression of CYP1A with the lipophilicity of alkyl gallates and other phenolic compounds. Mutat. Res. 537 (1), 101-108.

Fischer, U., Schulze-Osthoff, K., 2005. New approaches and therapeutics targeting apoptosis in disease. Pharmacol. Rev. 57 (2), 187-215.

Fowler, P., Smith, K., Young, J., Jeffrey, L., Kirkland, D., Pfuhler, S., Carmichael, P., 2012 Reduction of misleading ("false") positive results in mammalian cell genotoxicity assays. I. Choice of cell type. Mutat. Research/Genetic Toxicol. Environ. Mutagen. 742 (1-2), 11-25.

Fujita, K., Kubo, I., 2002. Antifungal activity of octyl gallate. Int. J. Food Microbiol. 79 (3), 193-201.

Furfaro, A.L., Traverso, N., Domenicotti, C., Piras, S., Moretta, L., Marinari, U.M., 
Pronzato, M.A., Nitti, M., 2016. The Nrf2/HO-1 Axis in cancer cell growth and chemoresistance. Oxidative Med. Cell. Longev. 2016, 1958174.

Furukawa, A., Oikawa, S., Murata, M., Hiraku, Y., Kawanishi, S., 2003. (-)-Epigallocatechin gallate causes oxidative damage to isolated and cellular DNA Biochem. Pharmacol. 66 (9), 1769-1778.

Galati, G., O'Brien, P.J., 2004. Potential toxicity of flavonoids and other dietary phenolics: significance for their chemopreventive and anticancer properties. Free Radic. Biol. Med. 37 (3), 287-303.

Garaj-Vrhovac, V., Durinec, M., Kopjar, N., Orescanin, V., 2008. A survey on the cytogenetic status of the Croatian general population by use of the cytokinesisblock micronucleus assay. Mutat. Res. 649 (1-2), 91-100.

Garattini, S., Bertele, V., 2002. Efficacy, safety, and cost of new anticancer drugs. BM] Br. Med. J. 325 (7358), 269-271.

Geismann, C., Arlt, A., Sebens, S., Schäfer, H., 2014. Cytoprotection "gone astray": Nrf2 and its role in cancer. OncoTargets Ther. 7, 1497-1518.

Glei, M., Pool-Zobel, B.L., 2006. The main catechin of green tea, (-)-epigallocatechin3-gallate (EGCG), reduces bleomycin-induced DNA damage in human leucocytes. Toxicol Vitro 20 (3), 295-300.

Greene, N., Naven, R., 2009. Early toxicity screening strategies. Curr. Opin. Drug Discov. Devel 12 (1), 90-97.

Gulati, D.K., Witt, K., Anderson, B., Zeiger, E., Shelby, M.D., 1989. Chromosome aberration and sister chromatid exchange tests in Chinese hamster ovary cells in vitro. III. Results with 27 chemicals. Environ. Mol. Mutagen 13 (2), 133-193.

Hashimoto, Y., Shimada, Y., Itami, A., Ito, T., Kawamura, J., Kawabe, A., Kaganoi, J. Maeda, M., Watanabe, G., Imamura, M., 2003. Growth inhibition through activation of peroxisome proliferator-activated receptor gamma in human oesophageal squamous cell carcinoma. Eur. J. Cancer 39 (15), 2239-2246.

Hour, T.C., Liang, Y.C., Chu, I.S., Lin, J.K., 1999. Inhibition of eleven mutagens by various tea extracts, (-)epigallocatechin-3-gallate, gallic acid and caffeine. Food Chem. Toxicol. 37 (6), 569-579.

Hsu, C.L., Lo, W.H., Yen, G.C., 2007. Gallic acid induces apoptosis in 3T3-L1 preadipocytes via a Fas- and mitochondrial-mediated pathway. J. Agric. Food Chem. 55 (18), 7359-7365.

Hsu, F., Chen, P., Chang, H., Shang-Tzen, C., 2009. Effects of alkyl chain length of gallates on their antifungal property and potency as an environmentally benign preservative against wood-decay fungi. Int. Biodeterior. Biodegrad. 63 $543-554$.

Inoue, M., Suzuki, R., Sakaguchi, N., Li, Z., Takeda, T., Ogihara, Y., Jiang, B.Y., Chen, Y. 1995. Selective induction of cell death in cancer cells by gallic acid. Biol. Pharm. Bull. 18 (11), 1526-1530.

Isuzugawa, K., Inoue, M., Ogihara, Y., 2001. Ca2+-Dependent caspase activation by gallic acid derivatives. Biol. Pharm. Bull. 24 (7), 844-847.

Kansanen, E., Kuosmanen, S.M., Leinonen, H., Levonen, A.-L., 2013. The Keap1-Nrf2 pathway: mechanisms of activation and dysregulation in cancer(). Redox Biol. 1 (1), 45-49.

Kiechle, F.L., Zhang, X., 2002. Apoptosis: biochemical aspects and clinical implications. Clin. Chim. Acta $326(1-2), 27-45$.

Knasmuller, S., Parzefall, W., Sanyal, R., Ecker, S., Schwab, C., Uhl, M., MerschSundermann, V., Williamson, G., Hietsch, G., Langer, T., Darroudi, F. Natarajan, A.T., 1998. Use of metabolically competent human hepatoma cells for the detection of mutagens and antimutagens. Mutat. Res. 402 (1-2), 185-202.

Kratz, J.M., Andrighetti-Frohner, C.R., Kolling, D.J., Leal, P.C., Cirne-Santos, C.C., Yunes, R.A., Nunes, R.J., Trybala, E., Bergstrom, T., Frugulhetti, I.C., Barardi, C.R. Simoes, C.M., 2008. Anti-HSV-1 and anti-HIV-1 activity of gallic acid and penty gallate. Mem. Inst. Oswaldo Cruz 103 (5), 437-442.

Kubo, I., Fujita, K., Nihei, K., Nihei, A., 2004. Antibacterial activity of akyl gallates against Bacillus subtilis. J. Agric. Food Chem. 52 (5), 1072-1076.

Kubo, I., Xiao, P., Fujita, K., 2002. Anti-MRSA activity of alkyl gallates. Bioorg Med. Chem. Lett. 12 (2), 113-116.

Kweon, M.H., Adhami, V.M., Lee, J.S., Mukhtar, H., 2006. Constitutive overexpression of Nrf2-dependent heme oxygenase-1 in A549 cells contributes to resistance to apoptosis induced by epigallocatechin 3-gallate. J. Biol. Chem. 281 (44), 33761-33772.

Lo, L.W., Stich, H.F., 1978. The use of short-term tests to measure the preventive action of reducing agents on formation and activation of carcinogenic nitroso compounds. Mutat. Res. 57 (1), 57-67.

Locatelli, C., Leal, P.C., Yunes, R.A., Nunes, R.J., Creczynski-Pasa, T.B., 2009. Gallic acid ester derivatives induce apoptosis and cell adhesion inhibition in melanoma cells: the relationship between free radical generation, glutathione depletion and cell death. Chem. Biol. Interact. 181 (2), 175-184. Epub 2009 Jul 2003.

Locatelli, C., Rosso, R., Santos-Silva, M.C., de Souza, C.A., Licinio, M.A., Leal, P. Bazzo, M.L., Yunes, R.A., Creczynski-Pasa, T.B., 2008. Ester derivatives of gallic acid with potential toxicity toward L1210 leukemia cells. Bioorg Med. Chem. 16 (7), 3791-3799. Epub 2008 Jan 3731.

Merkl, R., Hrádková, I., FIllp, V., ŠmIdrkal, J., 2010. Antimicrobial and antioxidant properties of phenolic acids alkyl esters. Czech J. Food Sci. 28 (4), 275-279.

Morais, M.C. Luqman, S., Kondratyuk, T.P., Petronio, M.S., Regasini, L.O., Silva, D.H. Bolzani, V.S., Soares, C.P., Pezzuto, J.M., 2010. Suppression of TNF-alpha induced NFkappaB activity by gallic acid and its semi-synthetic esters: possible role in cancer chemoprevention. Nat. Prod. Res. 24 (18), 1758-1765.

Morley, N., Clifford, T., Salter, L., Campbell, S., Gould, D., Curnow, A., 2005. The Green Tea Polyphenol (-)-Epigallocatechin Gallate and Green Tea can Protect Human Cellular DNA from Ultraviolet and Visible Radiation-Induced Damage.

Na, H.-K., Surh, Y.-J., 2008. Modulation of Nrf2-mediated antioxidant and detoxifying enzyme induction by the green tea polyphenol EGCG. Food Chem. Toxicol. 46 (4), 1271-1278.

Nakagawa, Y., Moldeus, P., Moore, G.A., 1996. Relationship between mitochondrial dysfunction and toxicity of propyl gallate in isolated rat hepatocytes. Toxicology 114 (2), 135-145.

Nakagawa, Y., Nakajima, K., Tayama, S., Moldeus, P., 1995. Metabolism and cytotoxicity of propyl gallate in isolated rat hepatocytes: effects of a thiol reductant and an esterase inhibitor. Mol. Pharmacol. 47 (5), 1021-1027.

Nakagawa, Y., Tayama, S., 1995. Cytotoxicity of propyl gallate and related compounds in rat hepatocytes. Arch. Toxicol. 69 (3), 204-208.

No, J.H., Kim, Y.-B., Song, Y.S., 2014. Targeting Nrf2 signaling to combat chemoresistance. J. Cancer Prev. 19 (2), 111-117.

Noda, N., Wakasugi, H., 2001. Cancer and oxidative stress. Jpn. Med. Assoc. J. 44, 535-539.

OECD, 2010. Test No. 487: in Vitro Mammalian Cell Micronucleus Test. OECD Publishing.

Pandır, D., 2015. Protective effect of (2)-epigallocatechin-3-gallateon capsaicininduced DNA damage and oxidative stress in human erythrocyes and leucocytes in vitro. Cytotechnology 67, 367-377.

Roy, G., Lombardia, M., Palacios, C., Serrano, A., Cespon, C., Ortega, E., Eiras, P., Lujan, S., Revilla, Y., Gonzalez-Porque, P., 2000. Mechanistic aspects of the induction of apoptosis by lauryl gallate in the murine B-cell lymphoma line Wehi 231. Arch. Biochem. Biophys. 383 (2), 206-214.

Saeki, K., Yuo, A., Isemura, M., Abe, I., Seki, T., Noguchi, H., 2000. Apoptosis-inducing activity of lipid derivatives of gallic acid. Biol. Pharm. Bull. 23 (11), 1391-1394.

Savi, L.A., Leal, P.C., Vieira, T.O., Rosso, R., Nunes, R.J., Yunes, R.A., CreczynskiPasa, T.B., Barardi, C.R., Simoes, C.M., 2005. Evaluation of anti-herpetic and antioxidant activities, and cytotoxic and genotoxic effects of synthetic alkylesters of gallic acid. Arzneimittelforschung 55 (1), 66-75.

Serrano, A., Palacios, C., Roy, G., Cespón, C., Villar, M. a. L., Nocito, M., GonzálezPorqué, P., 1998. Derivatives of gallic acid induce apoptosis in tumoral cell lines and inhibit lymphocyte proliferation. Archives Biochem. Biophysics 350 (1), 49-54.

Silva, I.C., Regasini, L.O., Petronio, M.S., Silva, D.H., Bolzani, V.S., Belasque Jr., J., Sacramento, L.V., Ferreira, H., 2013. Antibacterial activity of alkyl gallates against Xanthomonas citri subsp. citri. J. Bacteriol. 195 (1), 85-94. http:// dx.doi.org/10.1128/JB.01442-01412. Epub 02012 Oct 01426.

Stewart, B.W., Wild, C.P., 2014. World Cancer Report 2014. International Agency for Research on Cancer ; World Health Organization, Geneva, Swizerland, 2014.

Strlic, M., Radovic, T., Kolar, J., Pihlar, B., 2002. Anti- and prooxidative properties of gallic acid in fenton-type systems. J. Agric. Food Chem. 50 (22), 6313-6317.

Tammela, P., Laitinen, L., Galkin, A., Wennberg, T., Heczko, R., Vuorela, H., Slotte, J.P., Vuorela, P., 2004. Permeability characteristics and membrane affinity of flavonoids and alkyl gallates in Caco-2 cells and in phospholipid vesicles. Arch. Biochem. Biophys. 425 (2), 193-199.

Taraphdar, A.K., Roy, M., B, R.K., 2001. Natural products as inducers of apoptosis: implication for cancer therapy and prevention. Curr. Sci. 80 (11), 1387-1396.

Tayama, S., Nakagawa, Y., 2001. "Cytogenetic effects of propyl gallate in CHO-K1 cells. Mutat. Research/Genetic Toxicol. Environ. Mutagen, 498 (1-2), 117-127.

Tice, R.R., Agurell, E., Anderson, D., Burlinson, B., Hartmann, A., Kobayashi, H., Miyamae, Y., Rojas, E., Ryu, J.C., Sasaki, Y.F., 2000. Single cell gel/comet assay: guidelines for in vitro and in vivo genetic toxicology testing. Environ. Mol. Mutagen 35 (3), 206-221.

Uhl, M., Helma, C., Knasmuller, S., 2000. Evaluation of the single cell gel electrophoresis assay with human hepatoma (Hep G2) cells. Mutat. Res. 468 (2), $213-225$.

Wang, X.J., Sun, Z., Villeneuve, N.F., Zhang, S., Zhao, F., Li, Y., Chen, W., Yi, X., Zheng, W., Wondrak, G.T., Wong, P.K., Zhang, D.D., 2008. Nrf2 enhances resistance of cancer cells to chemotherapeutic drugs, the dark side of Nrf2. Carcinogenesis 29 (6), 1235-1243.

Wu, C.C., Hsu, M.C., Hsieh, C.W., Lin, J.B., Lai, P.H., Wung, B.S., 2006. Upregulation of heme oxygenase-1 by Epigallocatechin-3-gallate via the phosphatidylinositol 3-kinase/Akt and ERK pathways. Life Sci. 78 (25), 2889-2897.

Zheng, Y., Morris, A., Sunkara, M., Layne, J., Toborek, M., Hennig, B., 2012. EGCG stimulates Nrf2 and heme oxygenase-1 via caveolin-1 displacement. J. Nutr. Biochem. 23 (2), 163-168. 